\title{
The Effect of REACT Model Assisted Fable-Math Book Media on Mathematical Problem Solving Of Elementary School Students
}

\section{Destiana Dian Arfiani ${ }^{1}$, Himmatul Ulya ${ }^{2}$, Savitri Wanabuliandari ${ }^{3}$}

\author{
${ }^{1}$ Pendidikan Guru Sekolah Dasar, ${ }^{2,3}$ Pendidikan Matematika \\ Fakultas Keguruan dan Ilmu Pendidikan \\ Universitas Muria Kudus \\ destiana.arfi@gmail.com, himmatul.ulya@umk.ac.id, savitri.wanabuliandari@umk.ac.id
}

\begin{abstract}
This study aims to analyze (1) the average mathematical problem solving ability of students who can achieve the KKM, (2) the proportion of students who can complete classical completeness of $75 \%$, (3) differences in students' mathematical problem solving abilities before and after the REACT model assisted by fable-math book media is applied, (4) increasing mathematical problem solving abilities. The research method used is quantitative research with a pre-experimental design trial design in the form of one group pretest posttest. Sampling was done by means of purposive sample. The sample in this study were IV grade students in academic year 2019/2020. Collecting data using interview techniques, documentation, and tests. The data that has been collected is then analyzed using statistical analysis in the form of one sample t-test, z-proportion test, paired sample t-test, and n-gain test. After applying the REACT model assisted by the fable-math book media the results of the study showed that the average score of the student's problem-solving ability test got more than 70 , the proportion of students who completed the test could achieve classical completeness above $75 \%$, there were significant differences in the pretest and posttest results, and there is an increase in students' mathematical problem solving abilities with the medium category.

Keywords: Mathematical Problem Solving Ability, Fable-Math Book Media, REACT Models.
\end{abstract}

\section{INTRODUCTIONS}

Learning mathematics have important effects in improving the quality of education because mathematics as a source of various sciences. Mathematics as an important part of everyday life in all human activities and social matters. Agree with Kusmanto and Marliyana (2014), which states that mathematics is a fundamental science in the development of science and technology that can advance thinking skills and human disciplinary attitudes, mathematics also has an important role in solving all problems in life, therefore basic knowledge needs to be given to students as an understanding of mathematics. The purpose of learning mathematics in schools according to Permendiknas (2006) is that students have the ability to understand mathematical concepts, solve problems, using reasons, communicate ideas, and respect the usefulness of mathematics. In addition, with regard to the importance of solving mathematical problems, the research of the National Council of Teachers of Mathematics (NCTM) explains that in mathematics learning activities in schools, there are five mathematical abilities, namely: reasoning, problem solving, connection, communication, and representation (Sumartini, 2016: 149). The explanation of the importance of learning mathematics shows one of the important components to improve the quality of education is the ability solving the problems in mathematic. Problem solving is a process of finding a solution to a problem. According to 
Siregar and Syafari (2017) solving mathematical problems is a strategy to solve problems or questions on mathematical problems that involve students' abilities and in solving problems are not obtained directly. Therefore, the role of the teacher is an important thing that supports the improvement of student problem solving starting from increasing the ability of the students themselves and the choice of learning methods as well as various mathematical problem solving exercises. According to NCTM cited by Ulya (2016: 92) Mathematical problem solving has several indicators of solving, including (1) understanding new mathematical problems, (2) planning appropriate problem solving strategies, (3) doing problems solving, (4) monitoring and reflecting.

The fact occurs shows that in mathematics learning, activities related to problem solving have not been used as activities that must be carried out. The results of research from the Program for International Students Assessment (PISA) in 2018 showed the low problem-solving ability of Indonesian students in mathematics learning, this can be seen from the acquisition of an average test score for Indonesian students of 379 in the 74th rank of 79 countries that have researched. Regarding non-routine problems such as problem solving and proof in mathematics that require reasoning, students still need various guidance from the teacher in solving them (Fauziah, 2010). The main cause of the low ability of mathematical problems is the unenthusiastic attitude of students towards mathematics and the learning process which too often uses in learning methods directly, so that as a result, in solving math problems students only refer to the method given by the teacher (Siregar and Syafari, 2017). In general, learning mathematics in school, the teacher gives material and non-problem solving exercise.

The results of interviews conducted with IV grade students of SDN Gembong 01 Pati showed that most of students were not enthusiastic about taking mathematics lessons. Students feel mathematics is not a fun learning because it deals with numbers and calculations. If students are faced with problems related to problem solving, students are unable to understand these problems. Students need to be explained the meaning of each sentence in problem solving so that students understand the meaning of the problem so that they can present it in mathematical sentences. Students' lack of readiness in solving mathematical problems can be seen in the results of the problem solving ability test which was attended by 21 fourth grade students of SDN Gembong 01, it is known that there are 17 students who did not complete the KKM or the equivalent of $80.95 \%$ and there were 4 students who were declared complete or equal to $19,05 \%$ in doing questions. The average value obtained by students in the problem-solving test was 44.71 . The description of the test results shows that students have not been able to solve mathematical problem solving problems in accordance with the correct solving steps.

The low ability of students' problem solving is due to their unenthusiastic and lack of motivation towards learning mathematics in the classroom. It makes the students are not serious in learning mathematics caused in less meaningful learning. Less meaningful learning makes it difficult for students to remember what the teacher teaches. If students do not master the previous material, it is possible that students will have difficulty with the next material, because the first students' abilities are the basic of the next material. Efforts that can be applied to these problems are applying a learning model that provides direct experience to students so that learning can be easily remembered. One model that can be applied is the contextual model of Relating, Experiencing, Applying, Cooperating, and Transferring or more easily called the REACT model.

REACT learning model is a learning strategy that is contextual or real. The development of a contextual model proposed by Crawford (2003: iii) The REACT 
learning model has five main related stages, that are Relating, Experiencing, Applying, Cooperating, and Transferring. Relating is a pre-learning activity by linking concepts in everyday life experiences. Experiencing is the activity of finding new concepts to be learned. Applying is the activity of applying concepts in the question in form of problems. Cooperating is an activity to collaborate students with each other to solve problems. Transferring is using a concept into a new situation such as a class discussion. This REACT learning model has a gradual model step, from basic understanding to deep understanding that can help students' thinking skills (Anas and Fitriani, 2018: 160). Contextual learning invites students to be present in real life and encourages them to apply their knowledge. Contextual learning with the REACT model will make students more active in constructing their knowledge, not only accepting concepts from the teacher (Novri, et al, 2018).

In accordance with the REACT model, learning will be a meaningful experience for students when they imagine the context presented through the media. The media that is used as a complement in this learning is the fable-math book media. According to Haidar (2018) learning by presenting pictures in stories in the form of a math fable book is in accordance with the early stage group in the high class which is easy to understand and meets the needs of children. Fable books can develop reading interest in students and motivate students in learning (Oktaviani and Prihatin, 2019). The combination of the REACT model and fable-math book media will attract students' interest in learning mathematics by providing meaningful experiences. The REACT model which is contextual is suitable for the fable book media which contains realistic problems so that students are able to solve problems in life. In line with Fatmala, et al. (2016) suggest that the REACT contextual model directs students to learn to relate material concepts to their surrounding life, making it easier for students to find solutions to various problems.

According to Kristianti, et al. (2013) in their research, they stated that the use of the REACT model as contextual learning of students' mathematical problem-solving abilities has increased significantly. The use of fable-math book media is an effort to make learning more optimal than before. Therefore, the researcher wishes to conduct research on the effect of the REACT model assisted by fable-math book media on problem solving of elementary school students. This research has problem formulations including, (1) whether the average mathematical problem solving ability of students through learning with the REACT model assisted by fable-math book media can achieve KKM? (2) is the proportion of students completing the REACT model assisted by the fable-math book media can achieve $75 \%$ classical completeness? (3) is there a difference in the average ability of students' mathematical problem solving before and after the application of the REACT model assisted by fable-math book media? and (4) is there an increase in students' mathematical problem solving abilities through REACT model learning assisted by fablemath book media?

\section{RESEARCH METHOD}

The method used in this research is quantitative research. The research design used pre-experimental design in the form of one group pretest posttest. This research uses two variables, that are the independent variable and the dependent variable. The independent variable in this research is the REACT model assisted by the fabel-math book media, while the dependent variable is the students' mathematical problem solving ability. The sample 
selection technique is through purposive sampling technique. The sample used for this research were IV grade students of SDN Gembong 01 Pati in the 2019/2020 even semester learning. The number of class IV are 21 students, 10 male students and 11 female students. The design in this research is shown in table 1 as follows.

Table 1 Research Design

\begin{tabular}{cccc}
\hline Group & Pretest & Treatment & Posttest \\
\hline Experimen & $\mathrm{O}_{1}$ & $\mathrm{X}$ & $\mathrm{O}_{2}$ \\
\hline
\end{tabular}

(Source: Sugiyono, 2016)

Information:

$\mathrm{O}_{1} \quad=$ pretest (before treatment)

$\mathrm{O}_{2} \quad=$ posttest (after treatment)

$\mathrm{X} \quad=$ given treatment (independent variable)

Based on table 1, the research design was initially given a pretest test to determine first ability, then the sample was given treatment using the REACT model with the help of the fable-math book media, and after that the sample was given the final test, is posttest to determine its effect on mathematical problem solving abilities. The techniques used in collecting research data are interview techniques, documentation techniques, and tests. The research instruments used were test and non-test, the test instrument used was in the form of pretest and posttest questions and the non-test instrument in the form of an interview sheet. The data that has been known in the test results are then analyzed using statistical calculations in the form of a one-sample t-tets test to determine the average individual completeness of the student's test results, the proportion $\mathrm{z}$ test is used to determine the level of the proportion of students who completed the test on the classical student learning completeness, the paired sample t-test was conducted to determine the difference between the average ability of students before and after being treated, and $n$ gain was used to determine the increase in students' mathematical problem solving abilities.

\section{RESULTS}

Before testing the hypothesis with the statistical test, the data is analyzed first using the data normality test. The data normality test in this research used the KolmogorovSmirnov test with the help of the SPSS 25 application. Based on the data normality test, it was concluded that the experimental group had normal distribution data. Achievement of students' completeness in mathematics test results refers to the minimum completeness criteria (KKM) that have been determined by the education unit, which is more than equal to 70 .

\section{Individual learning completeness}

The results pretest of the problem-solving abilities of IV grade students showed that $19.05 \%$ of the students had completed the KKM, and $80.95 \%$ of the students did not complete the KKM. While the results of the posttest or final test after treatment obtained different mastery results. Grade IV students who passed the KKM in the posttest were $76.19 \%$ of students, for students who did not complete the KKM were $23.81 \%$. This shows that the difference in student learning completeness has increased. After knowing the 
results of the students' initial and final tests, then the average individual learning completeness test was carried out on the student's test scores to determine the KKM completeness achievement. The results of the calculation of completeness with the one sample t-test are clarified in the following table.

Table 2 The Results of the One Sample T-test

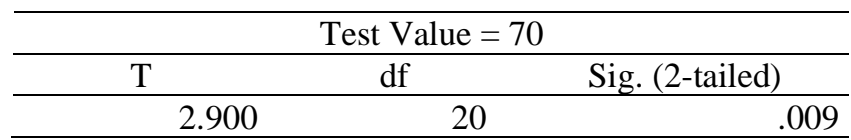

Based on table 2, it shows that the results of the one sample test show that the sig (2-tailed) result is 0,009 with a test value of 70 . Testing on this data uses one-part test, so to determine the sig value, namely yaitu $\frac{1}{2} \times 0,009=0,0045$. So that the results obtained sig $<0,05$ namely $0,0045<0,05$, which means that $\mathrm{H}_{0}$ is rejected and $\mathrm{H}_{\mathrm{a}}$ is accepted. So it can be concluded that the average result of the test results of students' mathematical problem solving abilities with the REACT model assisted by the fable-math book media gets more than 70 .

The REACT learning model invites students to find material concepts, collaborate, apply the knowledge gained in students' lives, and share in new situations, so that not only teach concepts but students are directed to find meaning in learning. According to Jelatu, et al. (2018) innovative learning with the REACT strategy can strengthen students' memory because they have experience concrete concept discovery. In addition, the fablemath book media used in this learning contains material on the circumference and wide of a flat shape which is packaged in the form of a pictorial story and used as a contextual tool. This fable-math book media is associated with the local excellence of the Pati area, making it easier for students to understand what material is being studied and obtained. This is in accordance with the opinion of Ulya (2016) that ethno-mathematics learning makes it easier for students to understand the concept of material because it provides direct experience related to local culture. In line with Wanabuliandari and Purwaningrum (2018), stated the use of the environment in the form of a surrounding culture that is associated with student knowledge can make learning more enjoyable and meaningful.

\section{Classical learning completeness}

Classical learning completeness in this research to determine the number of students who completed the test could reach $75 \%$ of the total number of students who received the REACT learning model assisted by the fable-math book media. This test uses the $\mathrm{Z}$ test of proportions assisted by Microsoft Excel 2010. Data from the students' pretest and posttest results are used to analyze classical learning completeness. The calculation of the $\mathrm{z}$ test proportion at the pretest value is clarified in the following table.

Table 3 Z-Test Results for Pretest

\begin{tabular}{ccc}
\hline$Z_{\text {hitung }}$ & $-Z_{\text {tabel }}$ & Conclusion \\
\hline$-5,921$ & $-1,645$ & $\mathrm{H}_{0}$ rejected
\end{tabular}

Based on table 3 shows the results of the pretest value data test shows $Z_{\text {hitung }}<-$ $\mathrm{Z}_{\text {tabel }}$ that is $-5,921<-1,645$. So that $\mathrm{H}_{0}$ is rejected and $\mathrm{H}_{\mathrm{a}}$ is accepted. So it can be concluded that the proportion of students who completed the test of students' mathematical 
problem solving abilities classically was less than $75 \%$ of the total number of students who took the pretest. There is also a proportional $\mathrm{z}$ test on the posttest tilapia in the following table.

Table 4 Z-Test Results for Posttest

\begin{tabular}{ccc}
\hline$Z_{\text {hitung }}$ & $-Z_{\text {tabel }}$ & Conclusion \\
\hline 0,126 & $-1,645$ & $\mathrm{H}_{0}$ accepted
\end{tabular}

Based on table 4, the $\mathrm{z}$ test results are obtained on the posttest value data, namely $Z_{\text {hitung }}>-Z_{\text {tabel }}$ with a value of $0.126>-1.645$. So that $\mathrm{H}_{0}$ can be accepted. Then the conclusion is drawn that the proportion of students who complete the test of students' mathematical problem solving abilities classically is more than equal to $75 \%$ of the total number of students who take the posttest. For this reason, the use of the REACT learning model assisted by the fable-math book media has an effect on the mathematical problem solving abilities of IV grade students of SDN Gembong 01 Pati. Judging from the $\mathrm{z}$ test of classical student learning completeness on the final test results it can be concluded that the final score (posttest) of students can reach the predetermined minimum completeness criteria (KKM). In accordance with the research of Fatmala, et al (2016) that students' problem-solving abilities in mathematics after applying the REACT contextual learning model can increase with a classical average in cycle 1 of $58 \%$, while in cycle II the classical average is $74 \%$.

Learning activities with the REACT model students are formed in heterogeneous groups to improve the development of students' abilities and skills. Herlina, et al (2012) stated that learning with the REACT strategy can develop problem-solving skills, present ideas and concepts from all perspectives through group learning as an effort to shareresponding-communicating with other students effectively. At the stage of cooperating activities or in groups, students' social care attitudes in learning were also seen. Students who have high understanding are more concerned with their group mates who do not understand the meaning of the material concept and problem solving problems, so that students can develop their abilities. This is reinforced by the statement of Asmahasanah, et al. (2018: 58) that REACT learning is good for elementary school social education because it is able to form an attitude of togetherness between students, form caring around, and deepen student understanding.

\section{Difference in average}

The effect on the application of the REACT model assisted by the fabel-math book media on students' mathematical problem solving abilities can be seen through the analysis of the mean difference. This average difference test is through the $t$ test (Paired Sample TTest) with the help of the SPSS 25 application. The t test (Paired Sample T-test) is clarified in the following table.

Table 5 Paired Sample T-test Results

\begin{tabular}{|c|c|c|}
\hline $\mathrm{t}$ & Df & Sig. (2-tailed) \\
\hline-15.338 & 20 & .000 \\
\hline
\end{tabular}

Based on table 5, it shows that the results of this data test are sig (2-tailed) $<0.05$, namely $0.000<0.05$, then $\mathrm{H}_{0}$ is rejected and $\mathrm{H}_{\mathrm{a}}$ is accepted. So it can be concluded that the use of the REACT learning model assisted by the fable-math book media has an effect 
on the mathematical problem solving abilities of the fourth grade students of SDN Gembong 01 Pati. The application of the REACT model assisted by the fable-math book media shows that after being treated with the REACT model and the fable book media, the results of the students' mathematical problem solving abilities test are better than before being given the treatment. When learning with this model students have enthusiasm and enthusiasm which can be seen in the seriousness of students in paying attention to and following the learning steps that have just been received. This can make students' confident attitude to solve problems. In accordance with the opinion of Putri and Santosa (2015), courage and self-confidence in students can have an influence in solving problems related to life around them.

The fable-math book media presented in the form of pictorial stories is used as a concrete form in learning, because grade IV students find it easier to digest something real. In line with Meylana, et al. (2019) stated that elementary school students have a way of thinking on the basis of concrete things, they need something real in the form of stories and pictures that can be found in their daily lives. In addition, the use of fable-math book media has an effect by making learning more fun and meaningful so that it can make it easier for students to understand and solve problems. For this reason students are able to solve problems starting from the stage of understanding the problem, planning solutions, and solving the problem. In Gunzel and Binterova's research (2016), it explains that media in the form of images can make it easier for students to understand mathematics learning and at the same time foster students' interest in learning.

\section{Improving Problem Solving Ability}

The analysis used to determine the increase in student ability is the N-gain test carried out in the Microsoft Excel 2010 application. The use of the N-gain test is to see the comparison of the results of the pretest and posttest scores of fourth grade students with the predetermined ideal maximal score (SMI). In detail, the results of the calculation of the N-gain test on the students' mathematical problem-solving ability test are described in the following table.

Table 6 N-Gain Test Results

\begin{tabular}{cccc}
\hline Pretest & Posttest & N-gain & Criteria \\
\hline 55,83 & 77,34 & 0,512 & Moderate
\end{tabular}

In table 6, it is found that the results of the calculation of the N-gain test of students have increased the students' mathematical problem solving abilities by 0.512 . This means that the increase in students' mathematical problem solving abilities is in the medium category. The analysis of improvement is in accordance with the criteria for improvement in the following table.

Table 7 Student Improvement Analysis

\begin{tabular}{|c|c|c|}
\hline Criteria & Banyak Siswa & Presentase \\
\hline High & 2 & $9,52 \%$ \\
\hline
\end{tabular}




\begin{tabular}{lcc}
\hline \multicolumn{1}{c}{ Criteria } & Banyak Siswa & Presentase \\
\hline Moderate & 16 & $76,19 \%$ \\
Low & 3 & $14,23 \%$ \\
There was no improvement & 0 & $0 \%$ \\
There was a decline & 0 & $0 \%$
\end{tabular}

Table 7 explains that the increase in problem-solving abilities most often occurs in moderate criteria, namely $76.19 \%$ of 16 students. The increase in the low category was 3 students with a percentage rate of $14.23 \%$. The increase in the high category was obtained by 2 students or the equivalent of $9.52 \%$. In addition, there are no student gains who are in the category where there is no decline and there is a decrease.

The increase in students' mathematical abilities in the circumference and wide flat shapes was due to the use of the REACT contextual model assisted by the media of a fable-math book containing pictures with stories of local excellence. The learning model and new learning media they receive make enthusiasm and high motivation. According to Ardianti, et al. (2019: 8) learning media associated with local culture can make it easier for students to understand the concept of the material then make the learning they receive more meaningful, as well as teacher teaching skills related to classroom management can be improved. In addition, it is reinforced by the results of Haidar's research (2018) that the media in learning mathematics in the form of fable story books can improve mathematics learning outcomes in grade IV students of SDN 2 Tulungagung. At the time of implementing the REACT Model, which is accompanied by the fable-math book media, students seem to find it easier to catch and follow the steps to solve the problem, because in the mathematics fable book there are stages for problem solving. Agree with Pardimin and Widodo (2016) suggesting that learning will be more effective by providing guidance to students differently, one of which is the development of additional books such as story books that are equipped with stages in problem solving.

\section{CONCLUSION}

Based on the results of the research above, the following conclusions were obtained: (1) the use of the REACT model assisted by the fable-math book media on the average mathematical problem solving ability of the fourth grade students of SDN Gembong 01 to reach the KKM, (2) the proportion of students completness with the REACT model assisted by the the fable-math book media can achieve $75 \%$ classical completeness, (3) the mathematical problem solving abilities of the fourth grade students before and after the implementation of the REACT learning model assisted by the fablemath book media experience significant differences, (4) through the REACT model assisted by the fable-math book media in Class IV learning can improve students' mathematical problem solving abilities. Some things that can be suggested are that the teacher should be more optimal in class management so that learning can fulfill what is wanted to be achieved, teachers who use this model must pay more attention to the syntax so that students can easily find the meaning of learning, and teachers should remind and 
provide directions to students to do it. questions carefully and carefully read the commands in the questions.

\section{REFERENCES}

Anas, A. \& A. Fitriani. (2018). Penerapan Model Pembelajaran REACT dalam Peningkatan Pemahaman Konsep Siswa. Al-Khwarizmi, Vol. 6 No. 2, 157-166.

Ardianti, S.D., Wanabuliandari, S., Wanabuliandario, S., \& Alimah, S. (2019). Respon Siswa dan Guru Terhadap Modul Ethno-Edutainment di Sekolah Islam Terpadu. Edukasia, Vol. 14 No. 1, 1-24.

Asmahasanah, S., Ibdalsyah, \& Sa'diyah, M. 2018. Social Studies Education in Elementary Schools Through Contextual REACT-Based on Environment and Sociopreneur. International Journal of Multicultural and Multireligious Understanding, Vol. 5 No. 6, 52-61.

Crawford, Michael L. 2001. Teaching Contextually Research, Rationale, and Techniques for Improving Student Motivation and Achievement in Mathematics and Science. Texas: CCI Publishing Inc.

Fatmala, K., Churiyah, M., \& Nora, E. (2016). Meningkatkan Kemampuan Pemecahan Masalah dan Hasil Belajar Siswa Melalui Model Pembelajaran Kontekstual REACT (Relating, Experiencing, Applying, Cooperating, dan Transferring). Jurnal Pendidikan Bisnis dan Ekonomi, Vol. 2 No. 1, 27-40.

Fauziah, A. (2010). Peningkatan Kemampuan Pemahaman dan Pemecahan Masalah Matematik Siswa SMP Melalui Strategi REACT. Forum Kependidikan, Vol. 30 No. $1,1-13$.

Gunzel, M. \& Binterova, H. (2016). Evaluation of Nonverbal Elements in Mathematics Textbooks. Universal Journal of Educational Research, Vol. 4 No. 1, 122-130.

Haidar, S.R. (2018). Pengembangan Buku Ajar Matematika Melalui Cerita Fabel Untuk Memperkuat Karakter Siswa Menggunakan Problem Based Learning Kelas IV Sekolah Dasar. Tesis Program Magister Keguruan Guru SD tidak diterbitkan, Universitas Lampung.

Herlina, S., Turmudi, \& Dahlan, J.A. (2012). Efektivitas Strategi REACT dalam Upaya Peningkatan Kemampuan Komunikasi Matematis Siswa Sekolah Menengah Pertama. Jurnal Pengajaran MIPA, Vol. 17 No. 1, 1-7.

Jelatu, S., Sariyasa, \& Ardana, I.M. (2018). Effect of GeoGebra-Aided REACT Strategy on Unsderstanding of Geometry Concepts. International Journal of Instruction, Vol. 11 No. 4, 325-336.

Kristianti, N.K.H., Sudhita, I.W.R., \& Riastini, P.N. (2013). Pengaruh Strategi REACT Terhadap Kemampuan Pemecahan Masalah Matematika Siswa Kelas IV SD Gugus XIV Kecamatan Buleleng. Ejournal Undiksha, 1, tanpa halaman.

Kusmanto, H. \& Marliyana, I. 2014. Pengaruh Pemahaman Matematika Terhadap Kemampuan Koneksi Matematika Siswa Kelas VII Semester Genap SMP Negeri 2 Kasokandel Kabupaten Majalengka. EduMa, Vol. 3 No. 2, 61-75. 
Meylana, D.A., Pujiastuti, P. \& Sartono, K.E. 2019. Lift The Flap Story Book Based on Child-Friendly: Improving The Ability of Students Mathematical Connection. Journal of Pshysics: International Conference Series, 1157 052065, 1-7.

Novri, U.S., Zulfah, \& Astuti. (2018). Pengaruh Strategi REACT (Relating, Experiencing, Applying, Cooperating, Transfering) Terhadap Kemampuan Pemahaman Konsep Matematis Peserta Didik Kelas VII SMP Negeri 1 Bangkinang. Jurnal Cendekia, Vol. 2 No. 2, 81-90.

Oktaviani, D. \& Prihatin, I. (2019). Pengembangan Bahan Ajar Matematika Berbasis Buku Fabel Berkarakter Untuk Siswa SMP. Jurnal SAP, Vol. 3 No. 3, 182-189.

Organization for Economic Coperation and Development (OECD). (2019). PISA 2018 Results Combined Executive Summaries Volume I, II \& III.

Pardimin, \& Widodo, S.A. 2016. Increasing Skills of Student in Junior High School to Problem Solving in Geometry with Guided. Journal of Education and Learning (EduLearn), Vol. 10 No. 4, 390-395.

Permendiknas Salinan Lampiran Menteri Pendidikan Nasional Nomor 22 Tahun 2006 Tentang Standar Isi untuk Satuan Pendidikan Dasar dan Menengah (2006). Jakarta: Permendiknas.

Putri, R.I. \& Santosa, R.H. (2015). Keefektifan Strategi REACT Ditinjau dari Prestasi Belajar, Kemampuan Penyelesaian Masalah, Koneksi Matematika, Self Efficacy. JRPM, Vol. 2 No. 2, 262-272.

Siregar, N.H. \& Syafari. (2017). Kemampuan Pemecahan Masalah Matematis Siswa Dalam Pembelajaran Matematika Menggunakan Model Pembelajaran PBL Dan TPS. SEMNASTIKA UNIMED.

Sugiyono. (2016). Metode Penelitian Pendidikan Pendekatan Kuantitatif, Kualitatif, dan $R \& D$. Bandung: Alfabeta.

Sumartini, T.S. (2016). Peningkatan Kemampuan Pemecahan Masalah Matematis Siswa melalui Pembelajaran Berbasis Masalah. Jurnal Mosharafa, Vol. 5 No. 2, 148-158.

Ulya, H. (2016). Pembelajaran Matematika Berbasis Etnomatematika untuk Membangun Karakter Cinta Tanah Air dan Kreativitas Belajar Matematika. PROSIDING, 29-39.

Ulya, H. (2016). Profil Kemampuan Pemecahan Masalah Siswa Bermotivasi Belajar Tinggi Berdasarkan IDEAL Problem Solving. GUSJIGANG, Vol. 2 No. 1, 9096.

Wanabuliandari, S. \& Purwaningrum, J.P. (2018). Pembelajaran Matematika Berbasis Kearifan Lokal GUSJIGANG Kudus pada Siswa Slow Learner. EduMa, Vol. 7 No. 1, 63-70. 